\title{
KRITIK NARASI POPULISME ISLAMIS DI MESIR PASCA-ARAB SPRING
}

\author{
Mush'ab Muqoddas Eka Purnomo
}

Abstrak

Al Ikhwan Al Muslimun sebagai organisasi Islamis paling lama yang bertujuan untuk mendirikan kembali Khilafah Islamiyyah, ternyata tidak mampu mengelola kekuasaan. Akhirnya tidak sedikit dari kader-kadernya beralih kepada ISIS karena dianggap lebih mampu mendirikan Khilafah Islamiyyah serta mampu melawan para penguasa karena memiliki kemampuan militer yang dianggap lebih baik, walaupun sebenarnya tidak. Walaupun, kegalatan pemikiran yang telah merusak nalar pikir Kaum Islamis, baik Al Ikhwan Al Muslimun ataupun Salafi, kita harus tetap membuka pintu dialog, karena bagaimanapun, mereka adalah bagian dari kita, Umat Islam.

Kata kunci : Umat Islam, Mesir, Al Ikhwan Al Muslimun, Salafi, ISIS 
Arab Spring mulai berkembang sejak 14 Januari 2011 di Tunis dari tragedi bunuh diri pembakaran seorang pemuda bernama Bouazizi yang merupakan lulusan ilmu komputer yang nasibnya buruk sehingga harus berjualan sayuran dan gerobaknya disita oleh aparat keamanan dengan alasan penertiban jalan. Aksi tersebut memicu kemarahan publik sehingga rezim mendiang Presiden Zainuddin Bin Ali tumbang. Angin protes Arab Spring menjalar ke berbagai penjuru Negara Arab menarget rezim-rezim yang berkuasa.

Selanjutnya, 25 Januari 2011 di Tahrir Square demonstrasi yang berawal sekitar 500 orang semakin besar, khususnya pada 28 Januari 2011 setelah banyak penjara dijebol dan hyper-market dijarah. Presiden Husni Mubarak mengangkat kepala GIS (General Intelligent Service) Letjen. Umar Sulaiman sebagai wakil presiden untuk mengadakan dialog-dialog dengan seluruh elemen politik. Hasilnya, Presiden Husni Mubarak harus mandeg pandito yang diumumkan oleh wakilnya sendiri. Kepemimpinan nasional diserahkan kepada SCAF (Supreme Council of Army Force) yang dikepalai oleh Menhan Jenderal Besar Muhammad Husain Thanthawi. Rakyat Mesir dan bahkan dunia internasional menganggap mundurnya Presiden Husni Mubarak merupakan angin kebebasan dan awal dari proses demokratisasi.

\section{Perubahan Narasi Populisme Islamis di Mesir Pasca Arab Spring}

Apakah Revolusi 25 Januari 2011 memang diyakini sebagai proses demokratisasi oleh Kaum Islamis (Al Ikhwan Al Muslimun, Salafi, dsb) di Mesir? Ternyata tidak. Mahir Farghali (2014) meyakini bahwa pasca Revolusi 25 Januari 2011 elemen-elemen Kaum Islamis, khususnya Salafi, akan mengalami perubahan drastis dan semakin radikal dengan terlibat aksi-aksi demonstrasi yang dianggap sebagai tujuan untuk menegakkan Syariat Islam. Hal ini mengingat Salafi yang identik dengan anti-demokrasi yang salah satu tatacara berdemokrasi adalah melakukan aksi-aksi demonstrasi sebagai bentuk protes. Perubahan yang drastis tersebut akan semakin beragam khususnya dari kalangan Salafi Sururi dan Salafi Jihadis yang akan membentuk berbagai kelompok-kelompok bersenjata untuk melakukan aksi-aksi kekerasan. ${ }^{1}$

Sebagai peneliti yang ingin mengetahui langsung peta kelompok-kelompok Islamis, Mahir Farghali, menjelang Pilpres 2012 meninjau langsung kemah-

1 Farghali, Mahir. Saradib As Salafiyyin (Tenda Kaum Salafi). Cairo: Kenouz. 2014. Hal. 83-86 
kemah yang ada di Tahrir Square di antaranya bertuliskan 'Salafi Revolusioner' dan mendapatkan sejumlah pemuda Salafi pengikut tokoh Salafi Sururi Hazim Abu Ismail $^{2}$ yang mengklaim menolak pilpres bahkan menyebut Muhammad Mursi pengkhianat Umat Islam yang digerakkan oleh Amerika Serikat dan Tentara Mesir, dan mengklaim telah membentuk kelompok Jihadis bernama Wadiy An Nil Al Jihadiyyah dengan tujuan menumbangkan para Thaghut. Selanjutnya, Mahir Farghali juga menemukan kelompok lain yang menamakan dirinya Al Muntadhiruun yang digagas oleh aktifis Al Ikhwan Al Muslimun bernama Majdi Khafajah dan aktifis Jama'ah Tabligh bernama Muhammad Abdud Dayim yang berpandangan bahwa hijrahnya para Mujahidin ke Negeri Jihad (Suriah) adalah untuk menunggu munculnya Imam Mahdi Al Muntadhor. Majdi Khafajah juga mengklaim kelompoknya terlibat dalam aksi kerusuhan yang pada demonstrasi di sekitar gedung Kemendagri dan gedung Kemenhan. ${ }^{3}$ Maka, tidak heran jika aksi-aksi demonstrasi di Mesir pasca Revolusi 25 Januari 2011 berujung menjadi aksi kekerasan, karena adanya infiltrasi Salafi.

Sebenarnya, penggunaan aksi-aksi kekerasan dalam sejarah Salafi bukanlah hal yang baru. Klaim reformasi keagamaan yang dilakukan oleh Wahabisme saat akan menguasai seluruh Semenanjung Arab dengan berdalih menyatukan Umat Islam dilakukan dengan cara meneror dan menekan Umat Islam yang tidak sepaham akidah dengan mereka, dengan ancaman senjata dan aksi kekerasan. ${ }^{4}$ Tentunya, tidak heran jika Kaum Islamis yang memanfaatkan kondisi yang tidak stabil melancarkan aksi-aksi kekerasan untuk menggalang opini sebagai pihak yang sangat berpengaruh dalam peta politik dan penentu stabilitas keamanan.

\section{Standar Ganda Narasi Kampanye Populis Al Ikhwan Al Muslimun}

Demi menggalang suara dari masyarakat umum dan menarik simpati dari kalangan liberal-sekuler, Al Ikhwan Al Muslimun menggunakan narasi demokratisasi, anti korupsi dan akan menggalang semua elemen yang terlibat Revolusi 25 Januari 2011 untuk bersama-sama membangun pemerintahan yang demokratis. Sedangkan kepada kalangan Islamis (kader dan simpatisan Al Ikhwan Al Muslimun, Salafi, Al Jama'ah Al Islamiyah dan Jama'ah Tabligh),

2 Merupakan putra dari tokoh Al Ikhwan Al Muslimun, Shalah Abu Ismail. Pada tahun 2012 maju sebagai capres dari jalur independen akan tetapi didiskualifikasi oleh KPU Mesir.

3 Ibid, Hal. 93-100

4 Rahman, Fazlur (Penj. Hassun As Saray). Al Islam (Islam). Beirut: Arab Network for Research and Publishing. 2017. Hal. 313 
para pimpinan Al Ikhwan Al Muslimun mengkampanyekan Muhammad Mursi sebagai khalifah Umat Islam dan jika memenangkan pilpres akan menjadi langkah awal untuk mendirikan Khilafah Islamiyah. ${ }^{5}$ Tentu saja, nalar demokrasi dan nalar teokrasi tidak dapat disatukan.

Ahmad Ban (2013) sebagai mantan salah satu anggota biro politik Al Ikhwan Al Muslimun, mengungkapkan bahwa, bukan merupakan hal yang baru $\mathrm{Al}$ Ikhwan Al Muslimun melancarkan tipu muslihat dalam memenangkan setiap perhelatan politik. Seperti contoh pada Pemilu 1942 seorang juru kampanye dari Al Ikhwan Al Muslimun berteriak di kerumunan warga di kota Ismailia mengaku bahwa dirinya adalah kerabat politisi Partai Wafd Sulaiman Eid, akan tetapi memilih Hasan Al Banna. Hal ini dituliskan oleh tokoh senior Al Ikhwan Al Muslimun bernama Hassan Hathut dalam memoarnya. Para kader Al Ikhwan Al Muslimun melandaskan sikap dusta tersebut dari salah satu hadits Nabi Muhammad SAW, bahwa perang adalah tipu muslihat. Sayangnya, target dari tipu muslihat dalam perang adalah Kaum Kafir yang jelas memusuhi Umat Islam dan sedang dalam medan peperangan. Sehingga dapat disimpulkan bahwa kader-kader Al Ikhwan Al Muslimun menganggap musuh-musuh politiknya yang juga beragama Islam, seperti bukan seorang muslim. ${ }^{6}$

Standar ganda dan penggunaan terma-terma populis Islam bagi Al Ikhwan Al Muslimun bukanlah hal baru. Pasca tumbangnya Turki Utsmani, Raja Mesir Fuad I ingin mengklaim dirinya sebagai Khalifah yang memimpin seluruh Umat Islam dan keinginan ini disambut baik oleh Hasan Al Banna dengan memuji Fuad I sebagai Penjaga Al Qur'an dalam surat kabar Al Ikhwan Al Muslimun tertanggal 9 Februari 1937 dengan sebutan seluruh Umat Islam yang berjumlah 300 juta jiwa bersedia mengorbankan nyawanya bagi Fuad I. Saat pelantikan Faruq I menggantikan Fuad I, Hasan Al Banna menyebut Faruq I sebagai Amirul Mukminin dan menggelar demonstrasi sebagai dukungan bertema "Allah SWT Bersama Faruq I" menandingi aksi demonstrasi yang digelar Partai Wafd bertema "Rakyat Bersama PM Mustafa An Nahas" yang menentang klaim Faruq I sebagai Khalifah bagi seluruh Umat Islam. Padahal, sikap Hasan Al Banna tersebut merupakan langkah awal untuk mengamankan posisi Al Ikhwan Al Muslimun dari pemantauan Inggris yang menjadikan Mesir

5 Ban, Ahmad. Ikhwan wa Salafiyyun wa Dawa'isy (Al Ikhwan Al Muslimun, Salafi dan ISIS). Cairo. Mahrosa Center. 2017. Hal. 206-207

6 Ban, Ahmad. Al Ikhwan Al Muslimun wa Mihnat Al Wathan wa Ad Din (Al Ikhwan Al Muslimun; Ujian Bangsa dan Agama). Cairo: Nile Center. 2013. Hal. 121-122 
sebagai kerajaan monarki protektoratnya. ${ }^{?}$

\section{Nalar Perlawanan Al Ikhwan Al Muslimun Pasca Tumbang}

Pada akhir 2014, penulis berkesempatan menemani Prof. Salim Said yang tengah melakukan riset terkait peran militer dan perkembangan politik di Mesir. Prof. Salim Said mendapatkan gambaran bagaimana cara Al Ikhwan Al Muslimun memimpin pemerintahan yang terlalu tergesa-gesa dan tidak mampu membedakan kesalehan pribadi dengan kepentingan politik terlebih terkait memilih Jenderal Abdul Fattah As Sisi sebagai menteri pertahanan, hanya karena rajin menjalankan puasa sunnah senin dan kamis.

Prof. Muhammad Salim Al 'Awwa' menceritakan bahwa Presiden Muhammad Mursi selalu berbuka puasa hari senin dan kamis bersama Menhan Jenderal Abdul Fattah As Sisi yang merupakan 'ketua Partai Tentara' dengan segelas air dan dua biji kurma. Prof. Salim Said kemudian mendapatkan gambaran obyektif dari sosiolog senior Prof. Saaduddin Ibrahim ${ }^{9}$ bahwa Presiden Muhammad Mursi bukanlah figur yang bodoh karena menyandang gelar Ph.D dari salah satu perguruan tinggi di Amerika Serikat, akan tetapi para pimpinan di Maktab Irsyad Al Ikhwan Al Muslimun terlalu arogan sehingga Presiden Mursi menjadi korban dari kebodohan mereka. Prof. Salim Said memahami kondisi Al Ikhwan Al Muslimun tersebut karena sudah terlalu lama ditindas sehingga tidak terlatih mengelola kekuasaan. ${ }^{10}$

Ahmad Ban (2017) mengakui, bahwa setelah berkuasa, Al Ikhwan Al Muslimun tidak membentuk aliansi politik yang luas seperti janjinya kepada elemen-elemen liberal-sekuler, karena para petinggi organisasi khusus yang menguasai struktur keorganisasian Al Ikhwan Al Muslimun hanya memiliki nalar bagaimana berkuasa dan menciptakan krisis. Hal ini kemudian menjadi alasan yang

7 Okasya, Khalid. Umara Ad Dam (Para Penguasa Darah). Cairo: Sama. 2015. Hal. 64-67

8 Prof. Dr. Muhammad Salim Al 'Awwa merupakan salah satu kader moderat Al Ikhwan Al Muslimun yang pada Pilpres 2012 maju melalui jalur independen, akan tetapi tidak memperoleh suara yang signifikan, dan kemudian diangkat penasehat diangkat penasehat Presiden Muhammad Mursi. Karena proposal rekonsiliasi nasional yang digagasnya ditolak oleh Presiden Muhammad Mursi, karena tidak disetujui oleh Maktab Irsyad al Ikhwan al Muslimun, dia mengundurkan diri.

9 Pendiri Pusat Studi Pembangunan Ibnu Khaldun Center yang kantornya tidak jauh dari kantor Al Ikhwan Al Muslimun di distrik Muqatham Cairo. Prof. Salim Said mengaku pada tahun 2003 atau 2004 saat berada di Cairo ingin bertemu dan mewawancari Prof. Saaduddin Ibrahim, akan tetapi saat itu Prof. Saaduddin Ibraihm ditahan oleh aparat keamanan Mesir.

10 Said, Salim Haji. Ini Bukan Kudeta. Bandung: Mizan. 2018. Hal. 43-46 
kuat seluruh elemen politik termasuk Partai An-Nur yang berideologi Salafi, meninggalkan Al Ikhwan Al Muslimun dan Sehingga, satu-satunya cara yang digunakan oleh para pimpinan Al Ikhwan Al Muslimun adalah demonstrasi di jalanan yang berujung menjadi aksi-aksi kekerasan dengan menggerakkan ribuan kader dan simpatisan yang siap berjuang sampai titik darah penghabisan. Selain itu, Al Ikhwan Al Muslimun memiliki jaringan internasional yang telah melakukan berbagai upaya untuk mencitrakan bahwa Pemerintah Mesir saat ini tidak memiliki legitimasi politik. ${ }^{11}$

Terkait organisasi khusus, Khalid Okasya ${ }^{12}$ memiliki catatan hukum. Pencetus pembentukan organisasi khusus Al Ikhwan Al Muslimun adalah Muhammad Labib seorang kader dari kegiatan kepanduan. Gagasan tersebut disetujui oleh Wakil Mursyid Am Al Ikhwan Al Muslimun Muhammad Khamis Humaidah dan diberkati oleh Mursyid Am Al Ikhwan Al Muslimun Hasan Al Banna, pada tahun 1942, setelah kekalahan Al Ikhwan Al Muslimun dalam Pemilu dan mengantisipasi jika terjadi benturan dengan Pemerintah. Seluruh anggota organisasi khusus harus dan/atau pernah mendapat pelatihan kepanduan yang memiliki pangkat tingkatan yaitu Musa'id (pembantu), Muntasib (anggota), 'Amil (pelaksana) dan Mujahid (prajurit). ${ }^{13}$

Adapun Jaringan Internasional Al Ikhwan Al Muslimun adalah organisasiorganisasi di luar Mesir yang memiliki hubungan ideologi dengan Al Ikhwan Al Muslimun. Beberapa di antaranya adalah Al Ittihad Al 'Alamiy li Ulama' Al Muslimin, Rabithah Ulama' Al Muslimin, Rabithah Ulama' Asy Syari'ah (Negara Teluk), Ittihad Ulama' Afriqiya (Negara Afrika), Rabithah Al Aurubiyyin Al Muslimin (Negara Eropa), Al Majlis Al Islamiy Al A'la li Ad Da'wah (Indonesia), Haiah Ulama (Yaman), Rabithah Asy Syari'ah li Ulama wa Du'at (Sudan) dan Rabithah Ad Du'at (Kuwait).

Pada 13-14 Juli 2013 Jaringan Internasional Al Ikhwan Al Muslimun menggelar pertemuan di Istanbul Turki. Pertemuan tersebut dihadiri oleh Ibrahim Munir (Sekjend Jaringan Internasional Al Ikhwan Al Muslimun, WN Mesir berdomisili di Inggris), Mahmud Husain (Wasekjend Jaringan Internasional Al Ikhwan Al Muslimun, WN Mesir berdomisili di Inggris), Ali Muhammad Ahmad Jawisy

11 Ban, Ahmad. OpCit 2017. Hal. 64-65

12 Merupakan mantan perwira intelijen National Security Kemendagri Mesir dengan pangkat terakhir brigadir jenderal. Pada tahun 2018, diangkat sebagai anggota Dewan Nasional Pemberantasan Terorisme dan Radikalisme. 
(Muraqib Am Al Ikhwan Al Muslimun Sudan), Ibrahim Al Mashriy (Muraqib Am Al Ikhwan Al Muslimun Lebanon), Ali Basya Umar Haj (Muraqib Am Al Ikhwan Al Muslimun Afrika Timur), Muhammad Riyadl Syaqafah (Muraqib Am Al Ikhwan Al Muslimun Suriah), Muhammad Faraj Ahmad (Pimpinan Al Ikhwan Al Muslimun Kurdistan Irak), Ziyad Syafiq Muhaisin Ar Rawiy (Muraqib Al Ikhwan Al Muslimun Yaman), Syaikhan Abdul Rahman Muhammad Ad Diba'iy (Pimpinan Al Ikhwan Al Muslimun Yaman), Muhammad Al Hilali (Wakil Ketua II Gerakan At Tauhid wa Al Ishlah Maroko), Rasyid Al Ghanusyi (Ketua Partai An Nahdlah Tunis) dan Humam Sa'id (Muraqib Am Al Ikhwan Al Muslimun Yordania).

Hasil kesepakatan pertemuan tersebut di antaranya adalah mencitrakan Mesir sedang terjadi perang saudara antara militer dan rakyat, khususnya kepada Negara Barat. Peran yang diambil oleh para pimpinan dan tokoh Jaringan Internasional Al Ikhwan Al Muslimun ini adalah sebagai koordinator atas semua organisasi, LSM dan media massa yang memiliki afiliasi ideologi dengan Al Ikhwan Al Muslimun. ${ }^{14}$

\section{Narasi ISIS Lebih Menggoda}

ISIS yang muncul pada tahun 2012 merupakan organisasi teroris yang lebih berbahaya dari Al Qaeda, karena memiliki strategi militer yang lebih matang, seperti taktik pengerahan kekuatan infantri dengan senjata ringan yang didukung oleh kendaraan-kendaraan keveleri dengan persenjataan yang lebih berat dalam menguasai suatu wilayah. ISIS memiliki lima kata yang mampu menyihir siapapun untuk menjadi simpatisan dan bahkan kombatannya. Lima kata tersebut adalah hijrah, jama'ah, melawan Thaghut, infiltrasi dan Khilafah Islamiyyah. Melalui lima kata tersebut, ISIS mampu mendatangkan para simpatisannya dari berbagai penjuru dunia, bahkan menggalang dana. ${ }^{15}$

ISIS merupakan gambaran baru bagi model pemahaman agama Islam yang sangat radikal karena mengklaim telah menyatakan berdirinya kembali Khilafah Islamiyah. Pernyataan ini kemudian menarik simpati semua elemen radikal untuk bergabung sebagai bagian dari warga negara Khiflah Islamiyah,

14 Bakr, Ali. Ba'da Al 'Ashifah; Mustaqbal At Tandzim Ad Dauliy li Al lkhwan Al Muslimin (Pasca Badai; Masa Depan Jaringan Internasional Al Ikhwan Al Muslimun). State Of Egypt. Regional Center for Strategic Studies. Edisi I. September 2013. Hal. 2-3

15 Ath Thaukhiy, Syahin (Peny.). Tahdid Ma'alim Daulah Da'isy (Mengenal Lebih Detail Negara ISIS). Cairo: Al Markaz Al Mashriy li Al Buhuts wa Ad Dirasat Al Amniyyah. 2015. Hal. 38-39 
bahkan dari kalangan perempuan dan anak-anak. Para anggota dan simpatisan ISIS merasa lebih bangga dari para seniornya di Al Qaeda yang masih memilih hidup dan beraktifitas secara sembunyi-sembunyi. Sayangnya, penyebaran ideologi ISIS yang dilakukan secara lebih sporadis mengakibatkan para anggota dan simpatisan ISIS tidak lebih rapi dari Al Qaeda. ${ }^{16}$ Tidak mengherankan, jika ISIS dalam melancarkan aksi-aksinya bertumpa para lonely wolfs yang digalang secara sporadis.

Apakah kader-kader Al Ikhwan Al Muslimun termasuk dari target penggalangan ISIS? Jawabnya, iya. Hisyam An Najjar dalam tulisannya yang dilansir situs berita Al Arab Online pada 16 Februari 2018 mengungkapkan, alasan ribuan kader-kader muda Al Ikhwan Al Muslimun seperti Umar Ad Daib, anak dari pimpinan Al Ikhwan Al Muslimun Ibrahim Ad Daib, bergabung dengan ISIS pada tahun 2017 karena ISIS dianggap memiliki sumber daya yang cukup untuk balas dendam kepada aparat keamanan, setelah tewasnya komandan biro krisis Al Ikhwan Al Muslimun, dr. Muhammad Kamal dalam operasi keamanan pada Oktober 2016. Selain itu, ISIS juga dianggap memiliki kemampuan penguasaan lapangan yang cukup. ${ }^{17}$

Mental sebagai pihak yang kalah dalam pertarungan politik setelah Revolusi 30 Juni 2013, menjadikan sebagian kader Al Ikhwan Al Muslimun berpindah menjadi ISIS, tidak hanya terjadi pada Umar Ad Daib saja. Selain faktor balas dendam, faktor lain yang mendorong tentunya adalah faktor ideologis berupa kebencian yang lama ditanamkan akan seluruh rezim Negara Arab yang dianggap menindas rakyatnya sendiri, dan Al Ikhwan Al Muslimun dicitrakan sebagai pihak yang selalu membela rakyat, seperti narasi-narasi yang digunakan oleh Sayid Quthb menggambarkan seluruh penguasa Negara Arab adalah Kaum Quraisy.

\section{Kritik Nalar Populis Kaum Islamis}

Najih Ibrahim, sebagai senior para aktifis Islamis dalam tulisannya di SKH Shorouk pada tanggal 3 Agustus 2018 menjelaskan bahwa kritik atas pemahaman Sayid Quthb di internal Al Ikhwan Al Muslimun pada dekade 1990an digagas oleh mantan anggota Maktab Irsyad Al Ikhwan Al Muslimun Abdul Mun'im

16 Sinaga, Obsatar, Prayitno Ramelan \& Ian Montratama. Terorisme Kanan di Indonesia. Jakarta: Elex Media Komputindo. 2018. Hal. 107-111

17 Lihat, https://alarab.co.uk/ar/ 
Abul Futuh yang dikenal moderat, sehingga pada tahun 2006 tersingkir dari struktur organisasi Al Ikhwan Al Muslimun. Najih Ibrahim mencermati bahwa Sayid Quthb sendiri tidak menyebut kitab Fi Dzilali Al Qur'an sebagai kitab tafsir Al Qur'an, karena dalam kitab tersebut tidak menjelaskan ayat-ayat Al Qur'an dalam kaidah fikih atau akidah, tidak menjelaskan secara rinci makna jahiliyah, dianggap sebagai kitab suci oleh para kelompok Islamis, menggunakan narasi-narasi keimanan untuk menguasai dan kesalahan paling fatal adalah menggambarkan Al Ikhwan Al Muslimun sebagai Umat Islam di fase Makkah dan para pemimpin Negara Arab dan dunia Islam sebagai kafir Quraisy. Sayangnya, pemahaman dan penggambaran Sayid Quthb tersebut digunakan sebagai dalih politik dan landasan keagamaan seluruh kelompok Islamis baik Al Ikhwan Al Muslimun ataupun ISIS untuk menyerang siapapun yang berbeda pandangan, pemahaman dan kepentingan politik, termasuk di antara kelompok-kelompok Islamis sendiri. ${ }^{18}$

Terkait saling kritik dan saling mengkafirkan antar kelompok Islamis, Muhammad Taufiq (2015) menjelaskan bahwa saling kritik antar Kaum Islamis khususnya kalangan Jihadis pada masa kini, disebabkan lemahnya referensi kajian keilmuan sejak pertengahan terakhir dekade 1990an sehingga banyak dari kalangan aktifis Islamis khususnya Jihadis tidak memahami berbagai istilah seperti Al Imarah (daerah aktifitas), Asy Syura (musyawarah), Al Baiah (baiat), Ad Daulah Al Islamiyyah (Negara Islam), At Takfir (pengkafiran dan mekanismenya) dan As Sam'u wa Ath Tha'ah (mendengar dan menaati). Alhasil, kalangan Islamis khususnya Jihadis saat ini lebih radikal, lebih sektarian, lebih sektoral (mengutamakan kelompok atau faksinya saja) dan lebih angkuh. Sayangnya, kemampuan tempur dan kemampuan melancarkan aksi teror lebih lemah, terutama dalam penggunaan senjata. ${ }^{19}$

Nalar keilmuan kelompok-kelompok Islamis, tidak hanya di Mesir, akan tetapi mungkin juga di seluruh dunia, memang sudah melemah. Ahmad Ban (2013) menjelaskan alasan kenapa kader-kader Al Ikhwan Al Muslimun yang memiliki latar belakang akademik yang cemerlang, sangat sulit untuk kritis bahkan atas setiap keputusan dan kebijakan yang diambil oleh petinggi Al Ikhwan Al Muslimun. Jawabannya adalah pada doktrin As Sam'u wa Ath Tha' at (mendengar dan menaati) atas segala kebijakan dari para pimpinan Al Ikhwan

$18 \mathrm{https}: / /$ shorouknews.com/mobile/columns/view.aspx?cdate=03082018\&id=171ff495-f999-4b11-8960035d83f26cf5

19 Taufiq, Muhammad. An Naqd Adz Dzatiy 'inda Al Islamiyyin (Kritik Dialektika Kaum Islamis). Beirut: Nama Center. 2015. Hal. 163-167 
Al Muslimun yang di dalam nalar pikirnya dianggap sebagai perintah Allah SWT yang harus ditaati. Ketaatan tersebut dianggap sebagai barometer akan keimanan kepada Allah SWT. ${ }^{20}$

Najih Ibrahim (2014) menolak standar Kaum Islamis terkait pelaksanaan Hudud (hukuman) sebagai standar pelabelan sebuah negeri disebut sebagai negara Islam, karena syariat Islam juga mencakup muamalat keuangan, pernikahan dan segala perundangan terkait penertiban kehidupan umum bahkan konstitusi-konstitusi di seluruh negeri umat Islam. Ditegaskannya bahwa seluruh negeri Islam saat ini, dari Indonesia sampai Maroko, merupakan negara Islam, bukan negara Jahiliyah atau negara Kafir. Hal ini mengingat seluruh keprotokoleran di negeri-negeri Umat Islam, mengharuskan kepala negara dan pejabat lainnya menyelenggarakan kegiatan yang memperingati hari-hari besar Umat Islam seperti Idul Fitri, Idul Adha, Nuzulul Qur'an, Lailatu Qadar, Maulid Nabi Muhammad SAW, Tahun Baru Hijriyah, dan peringatan-peringatan berskala lokal lainnya. ${ }^{21}$

Perdana Menteri Maroko dan juga Ketua Partai Keadilan dan Pembangunan yang berideologi Al Ikhwan Al Muslimun, Saaduddin Al Utsmani (2017) mengakui bahwa salah satu penyebab utama radikalisme beragama salah memahami setiap keputusan, tindakan dan aktifitas Nabi Muhammad SAW sebagai sebuah Syariat. Mengutip Ibnu Athiyah Al Andalusi (Wafat 541 Hijriyah), Saaduddin Al Utsmani menyebutkan bahwa mengikuti Nabi Muhammad SAW adalah mengukuti ajarannya, manhaj hidup dan akidah tauhid yang dibawa kepada Umat Islam. Seperti contoh, pada Perang Khandaq ketika Nabi Muhammad SAW mengajak dua Sahabatnya bernama Sa'ad bin Mu'adz RA dan Sa'ad bin Ubadah RA untuk menyerahkan sepertiga hasil panen kurma Madinah kepada Kabilah Ghathafan agar keluar dari aliansi Quraisy Makkah, saran Nabi Muhammad SAW tersebut ditolak. Pada kisah ini, kita dapat meniru langkah musyawarah yang diambil oleh Nabi Muhammad SAW untuk mengambil kebijakan politik, di saat genting sekalipun. $^{22}$

20 Ban, Ahmad. OpCit 2013. Hal. 229

21 Ibrahim, Najih \& Hisyam An Najjar. Da'isy As Sikkin allatiy Tadzbahu AI Islam (ISIS; Pisau yang Menyembelih Islam). Cairo: Dar Asy Syuruq. 2014. Hal. 134

22 Al Utsmani, Saaduddin. At Tasharrufaat An Nabawiyyah As Siyasiyyah (Kebijakan Politik Nabi Muhammad SAW). Beirut: Arab Network For Research and Publishing. 2017. Hal. 92-95 


\section{Penutup}

Mencermati kondisi Timur Tengah yang berada dalam ancaman narasinarasi idoleologis yang berbahaya akan pondasi-pondasi falsafi negara-bangsa, Indonesia dapat belajar dari kondisi tersebut, agar tidak terjadi di Indonesia, atau dapat diminimalisir. Indonesia yang terdiri dari ribuan pulau dan ratusan suku serta enam agama merupakan 'anyaman' yang saling mengikat dan menguatkan nan harmonis.

Najih Ibrahim (2018) yang pada akhir tahun 2013 sampai menjelang akhir 2014 berkunjung ke Indonesia memenuhi beberapa undangan diskusi, menilai bahwa masyarakat Indonesia tidak terlalu mementingkan pergolakan dan permasalahan politik, karena mampu mandiri dan melihat bahwa perubahan untuk semakin baik berasal dari dalam diri sendiri bukan dari para pimpinan politik (bottom up). Selain itu, Najih Ibrahim yang juga menyaksikan kegiatan kampanye pada Pilpres 2014, merasa kagum dengan kedua capres yaitu Presiden Joko Widodo dan Letjen. (Purn.) Prabowo Subianto yang keduanya mengenakan pakaian yang sederhana, yang menunjukkan keduanya adalah figur yang mencintai dan ingin dekat rakyat. ${ }^{23}$

Muhammad Najib (2019) mengutip istilah Juan J. Linz menggambarkan bahwa Indonesia telah selesai memasuki tahap proses transisi demokrasi akan tetapi belum berhasil pada tahap konsolidasi demokrasi. Hal ini disebabkan transisi demokrasi dikendalikan oleh para elit yang dibesarkan oleh Orde Baru, sehingga para Pejuang Reformasi harus selalu bernegosiasi dan berkompromi dengan kekuatan-kekuatan politik lama yang masih mengendalikan dan mendominasi sektor ekonomi. Ancaman yang dihadapi dalam konsolidasi demokrasi saat ini adalah belum tumbuhnya budaya demokrasi, pragmatism dalam mengejar tujuan politik, politik transaksional, politik uang dan politik dinasti. Sedangkan ancaman terbesar dan paling berbahaya adalah tren populisme yang mengusung primordialisme terkait SARA yang menimbulkan disharmoni dan disentigrasi sosial di tengah masyarakat, terutama pasca kasus ujaran kebencian mantan Gubernur DKI Jakarta Basuki Tjahaja Purnama pada akhir 2016 lalu. ${ }^{24}$

Maka dari pada itu, dialog antar semua elemen sosial dan kelompok-kelompok politik, harus terus dibangun untuk menghindari kecurigaan yang dapat berkembang menjadi konflik di tengah masyarakat. Mesir sejak tahun 1995

23 Ibrahim, Najih. Min Warai AI Qadlban (Dari Balik Jeruji). Cairo: Dar Al Ma'arif. 2018. Hal. 244-252

24 Najib, Muhammad. Jalan Demokrasi. Jakarta: Republika Penerbit. 2019. Hal. 160-163 
sudah mulai mencoba berdialog dengan tokoh-tokoh Al Jama'ah Al Islamiyyah dan berhasil.

Jurnalis senior Makram Muhammad Ahmad (2003) yang terlibat langsung memantau proses revisi pemikiran Al Jama'ah Al Islamiyah Mesir sejak tahun 1995 menjelaskan kepada khalayak akan pentingnya proses moderasi dengan cara dialog, yang saat itu tidak mendapatkan respon positif dari masyarakat. Ditekankannya, para kader dan pimpinan Al Jama'ah Al Islamiyah adalah bagian yang tidak terpisahkan dari anak bangsa lainnya sehingga mereka perlu untuk diselamatkan khususnya dari tipu daya konspirasi-konspirasi yang merusak negeri dan anak bangsa lainnya. Upaya ini juga bertujuan untuk memperbaiki citra Islam sebagai agama yang rahmatan lil 'alamiin. ${ }^{25}$

25 Ahmad, Makram Muhammad. Muamarah am Muraja'ah (Konspirasi atau Revisi ?). Cairo: Dar Asy Syuruq. 2003. Hal. 210 


\section{Daftar Pustaka}

Ahmad, Makram Muhammad. Muamarah am Muraja'ah (Konspirasi atau Revisi Pemikiran ?). Cairo: Dar Asy Syuruq. 2003.

Al Jufri, Ali Zainul Abidin bin Abdurrahman. Al Insaniyyah Qabla At Tadayyun. (Kemanusiaan Sebelum Beragama). Abu Dhabi: Dar Al Faqih. 2015.

Al Utsmani, Saaduddin. At Tasharrufaat An Nabawiyyah As Siyasiyyah (Kebijakan Politik Nabi Muhammad SAW). Beirut: Arab Network For Research and Publishing. 2017.

Ath Thaukhiy, Syahin (Peny.). Tahdid Ma'alim Daulah Da'isy (Mengenal Lebih

Detail Negara ISIS). Cairo: Al Markaz Al Mashriy li Al Buhuts wa Ad Dirasat Al Amniyyah. 2015.

An Najjar, Hisyam (2018). Da'isy wa Al Ikhwan Niran I'lamiyyah Shadiqah Taksyifu Al Akadzib wa Ash Shillat Al Khafiyyah (Hubungan ISIS dan Al Ikhwan Al Muslimun). Diambil kembali dari Alarab.co.uk: https://alarab.co.uk/ar

Bakr, Ali. Ba'da Al 'Ashifah; Mustaqbal At Tandzim Ad Dauliy li Al Ikhwan Al Muslimin (Pasca Badai; Masa Depan Jaringan Internasional Al Ikhwan Al Muslimun). State Of Egypt. Regional Center for Strategic Studies. Edisi I. September 2013.

Ban, Ahmad. Al Ikhwan Al Muslimun wa Mihnah Al Wathan wa Ad Din (Al Ikhwan Al Muslimun; Ujian Bangsa dan Agama). Cairo: Nile Center. 2013.

Ban, Ahmad. Ikhwan wa Salafiyyun wa Dawa'isy (Al Ikhwan Al Muslimun, Salafi dan ISIS). Cairo. Mahrosa Center. 2017.

Farghali, Mahir. Saradib As Salafiyyin (Tenda Kaum Salafi). Cairo: Kenouz. 2014.

Ibrahim, Najih (2018). Khamsah Asbab Waraa Tahawwul Dhilal Sayid Quthb li Nasyri Al 'Unfi wa At Takfiri (Lima Sebab Fii Dhilalil Qur'an Sayid Quthb Menyebarkan Kekerasan dan Takfir). Diambil kembali dari Showouknews.com: https://shorouknews.com/mobile/columns/view. aspx? cdate $=03082018 \& \mathrm{id}=171 \mathrm{ff} 495-\mathrm{f} 999-4 \mathrm{~b} 11-8960-035 \mathrm{~d} 83 \mathrm{f} 26 \mathrm{cf5}$

Ibrahim, Najih. Min Warai Al Qadlban (Dari Balik Jeruji). Cairo: Dar Al Ma'arif. 2018. 
Ibrahim, Najih \& Hisyam An Najjar. Da'isy As Sikkin allatiy Tadzbahu Al Islam (ISIS; Pisau yang Menyembelih Islam). Cairo: Dar Asy Syuruq. 2014.

Najib, Muhammad. Jalan Demokrasi. Jakarta: Republika Penerbit. 2019.

Okasya, Khalid. Umara Ad Dam (Para Penguasa Darah). Cairo: Sama. 2015.

Rahman, Fazlur (Penj. Hassun As Saray). Al Islam (Islam). Beirut: Arab Network for Research and Publishing. 2017.

Said, Salim Haji. Ini Bukan Kudeta. Bandung: Mizan. 2018.

Sinaga, Obsatar, Prayitno Ramelan \& Ian Montratama. Terorisme Kanan di Indonesia. Jakarta: Elex Media Komputindo. 2018.

Taufiq, Muhammad. An Naqd Adz Dzatiy 'inda Al Islamiyyin (Kritik Dialektika Kaum Islamis). Beirut: Nama Center. 2015. 